\title{
Familial colorectal cancer Type X
}

INSERM

\section{Source}

INSERM. (1999). Orphanet: an online rare disease and orphan drug data base. Familial colorectal cancer Type X. ORPHA:440437

A rare, hereditary nonpolyposis colon cancer defined in individuals meeting the Amsterdam criteria for Lynch syndrome, but lacking germline mutations in the mismatch repair genes. It is characterized by a later onset, preferential involvement of distal colon and rectum, lower risk of developing extracolonic cancer, a higher adenoma/carcinoma ratio, a higher differentiation of tumor cells, a more heterogeneous tumor architecture and an infiltrative growth pattern, when compared to Lynch syndrome cases. 